Journal of Engineering and Applied Sciences 14 (11): 3746-3753, 2019

ISSN: 1816-949X

(C) Medwell Journals, 2019

\title{
Water Management in Al-Kamaliya Irrigation Canal using GIS, CROPWAT and HEC-RAS
}

\author{
${ }^{1}$ Ayad Talib, ${ }^{2}$ Husam H. Alwan and ${ }^{2}$ Zuhair A.W.AL Jwahery \\ ${ }^{1}$ Department of Civil Engineering, \\ ${ }^{2}$ College of Engineering, University of Kerbala, Kerbala, Iraq
}

\begin{abstract}
The goal of irrigation management is to use water in the most profitable way at sustainable production levels. Irrigation management is important, since, it helps determine future irrigation expectations. This study achieved to develop the management of Al-Kamaliya irrigation project in province of Kerbala in Iraq and improve its operation with the use of GIS, CROPWAT and HEC-RAS applications by developing a better scenario for irrigation and building a database for a good management of the project. The study showed that these programs could be used in building a good management of water irrigation canal.
\end{abstract}

Key words: GIS, HEC-RAS, irrigation, management, scenario, programs

\section{INTRODUCTION}

There are millions hectares of irrigated lands in the world of which most have poor irrigation efficiencies (Shahrokhnia and Javan, 2005). Under limited water resources, an efficient irrigation system must be attained. Irrigation is the artificial exploitation and distribution of water at project level aiming at application of water at field level to agricultural crops in dry areas or in periods of scarce rainfall to assure or improve crop production. The goal of irrigation management is to use water in the most profitable way at sustainable production levels. For production agriculture, this generally means supplementing precipitation with irrigation. In recent days, the management of water resources in Iraq have a great deal because the water sources decrease as the rapid increase in the water demands and the nature of climatic conditions in that region. Therefore, there is a need of water management if the water demand is less than available or the irrigation water requirement is greater than available and shortage of water is taking place. The Geographic Information System (GIS) was used in calculating areas to be irrigated, building database for the information required in irrigation management and analyzing it spatially. The program by FAO (CROPWAT 8.0) was used for estimating the water required for irrigation according to the crop pattern in the irrigated land while (HEC-RAS) for predicting scenarios to improve canal performance and water delivery quantities. Serede et al. (2015) conducted hydraulic analysis of irrigation canals using HEC-RAS Model in Mwea Irrigation Scheme, Kenya. The HEC-RAS Model was tested in terms of error estimation and used to determine canal capacity potential. Ghumman et al. (2004) evaluated hydraulic performance of an irrigation system in upper Swat canal irrigation system in NWFP Pakistan using the Simulation Model CanalMan. Maatooq and Kadhim (2016) analyzed the actual operation of Al-Ibrahim irrigation canal, South of Iraq and evaluated performance indicators using the program HEC-RAS. The study showed that simulation programs could be used in management of irrigation canals. It could be predict a better scenarios of flow in irrigation canals from simulation process.

Study area: Al-Kamaliya irrigation canal is located on the right side of the Euphrates River in the province of Karbala in Iraq. The project extends between latitudes $\mathrm{N} 32^{\circ} 47^{\prime}-32^{\circ} 72^{\prime}$ and longitudes E $44^{\circ} 01^{\prime}-44^{\circ} 14^{\prime}$. It is bordered to the North and East by Al-Musayyib town and Al-Hussainiya canal, to the South by Karbala main drain and to the West by desert region and Al-Razaza Lake. The area bounded by the above-mentioned boundaries amounts to about 5588 ha (22352 donums). Al-Kamaliya canal was excavated, since, 1980 and its lining with concrete. It start from Al-Hussainiya canal and it is about $17 \mathrm{~km}$ long from end of the branch canal BCl. Al-Kamaliya canal connected with $\mathrm{BCl}$, since, 2010 (Fig. 1 and 2).

Geometric data for the main canal (Al-Kamaliya) and distributaries: The longitudinal sections of the above canals were gathered from the Administrative of Irrigation in Kerbala city in Iraq including the bed level, bank top level, longitudinal bed slope, bed width and water level at different stations of the canals (Table 1 and 2).

Corresponding Author: Ayad Talib, Department of Civil Engineering, College of Engineering, University of Kerbala, Kerbala, Iraq 3746 


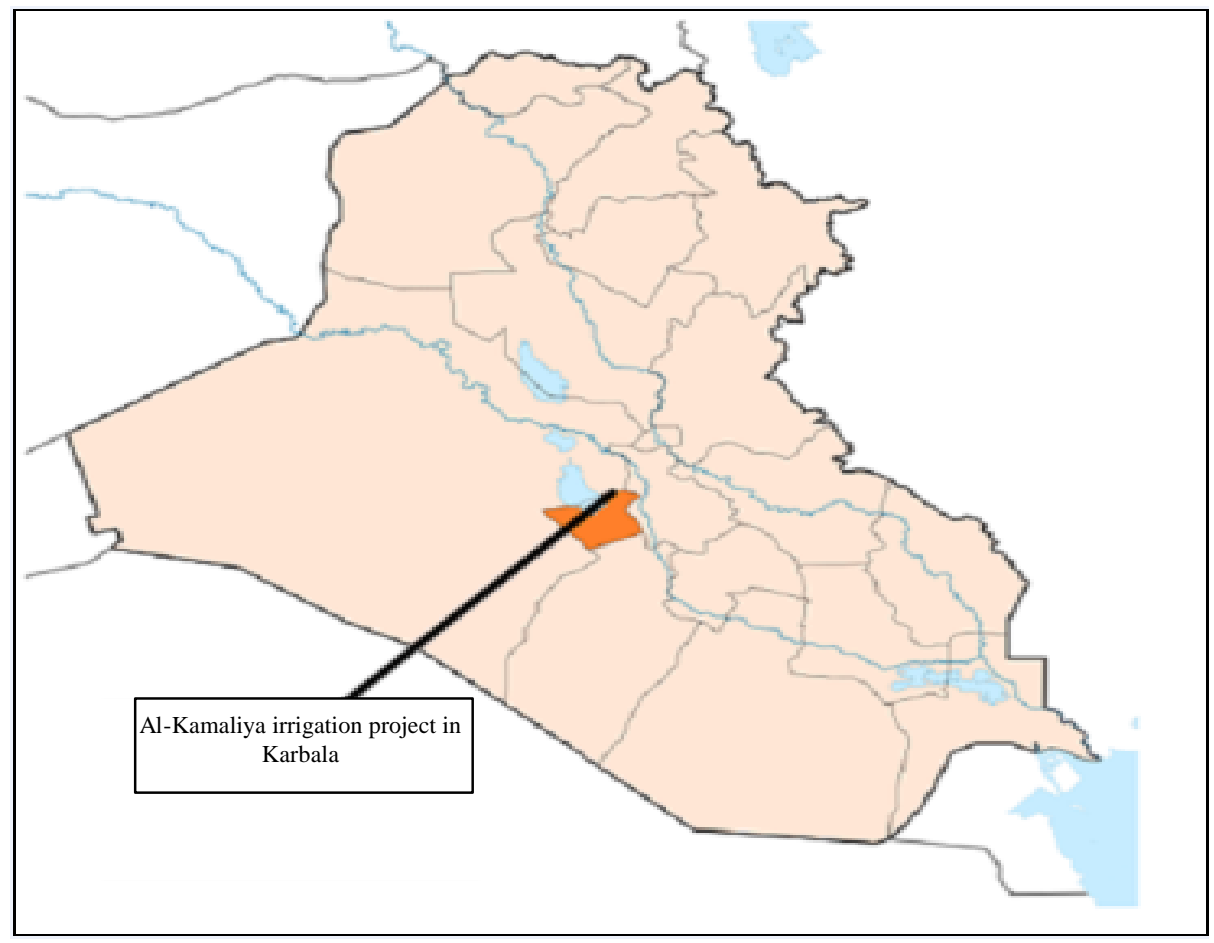

Fig. 1: The location of Al-Kamaliya canal in Kerbala city in Iraq

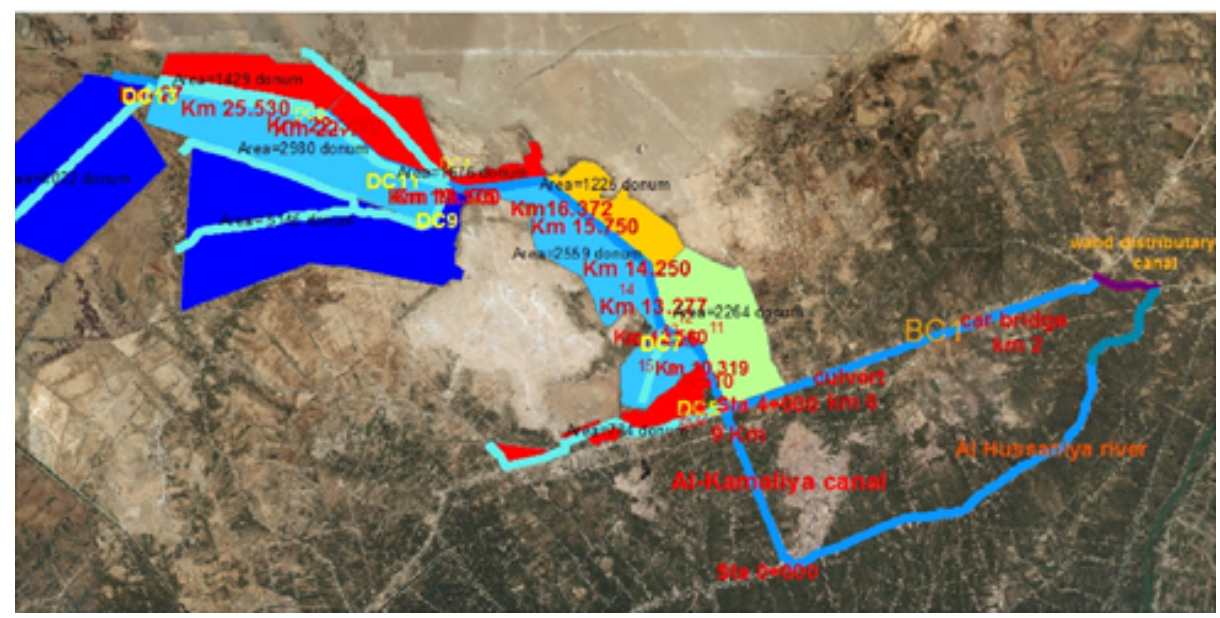

Fig. 2: Location of Al-Kamaliya canal

Table 1: (BC1) branch canal geometric data

\begin{tabular}{lcccccc}
\hline Stations & Bed channel elevation (m) & Water surface elevation $(\mathrm{m})$ & Water depth $(\mathrm{m})$ & Bed width $(\mathrm{m})$ & Design discharge $\left(\mathrm{m}^{3} / \mathrm{sec}\right)$ & Bed longitudinal slope \\
\hline 0 & 28.7 & 31 & 2.3 & 3 & 11 & 0.0001 \\
2 & 28.45 & 30.74 & 2.29 & 3 & - & 0.0001 \\
7 & 27.97 & 30.15 & 2.18 & 3 & - & 0.0001 \\
9 & 27.59 & 29.39 & 1.8 & 3 & - & 0.0001 \\
\hline
\end{tabular}

\section{Data used}

Climatic parameters: The main climatic parameters that affect crop water desires include: air temperature, humidity, prevailing wind speed, Sun shine duration, free-water surface evaporation and rainfall. Data from Karbala weather station have been gathered for the main climatic parameters which include mean maximum monthly air temperature, mean minimum monthly air temperature, 
Table 2: Al-Kamaliya canal geometric data

\begin{tabular}{llcccc}
\hline Station & Distributary canal & Minimum channel elevation (m) & Bank top level (m) & Bed width (m) & Bed longitudinal slope \\
\hline $4+000$ & - & 28.05 & 30.55 & 3 & 0.0001 \\
$4+100$ & DC5 & 28.03 & 30.53 & 3 & 0.0001 \\
$5+300$ & Cross regulator 1 & 27.8 & 30.30 & 1 & 0.0001 \\
$6+400$ & DC7 & 27.6 & 30.05 & 3 & 0.0001 \\
$13+500$ & DC9 & 26.500 & 28.500 & 2.8 & 0.0001 \\
$13+600$ & DC11, DC4 & 26.480 & 28.700 & 1 & 0.0001 \\
$13+700$ & Cross regulator 2 & 26.46 & 28.600 & 2.8 & 0.0001 \\
$16+500$ & DC8 & 26 & 28.100 & 2.8 & 0.0001 \\
$22+550$ & DC13 & 25.3 & 27.300 & 2.8 & 0.0001 \\
\hline
\end{tabular}

Table 3: Summary of climate parameters/Karbala station

\begin{tabular}{|c|c|c|c|c|c|c|c|c|c|c|c|c|}
\hline$\underline{\text { Parameters }}$ & Jan. & Feb. & Mar. & Apr. & May & Jun. & Jul. & Aug. & Sep. & Oct. & Nov. & Dec. \\
\hline Mean. min. temp $\left({ }^{\circ} \mathrm{C}\right)$ & 5.3 & 7.6 & 11.6 & 17.4 & 22.8 & 26.8 & 29.1 & 28.5 & 24.5 & 19.3 & 11.8 & 6.9 \\
\hline Mean. max. temp $\left({ }^{\circ} \mathrm{C}\right)$ & 16.2 & 19.2 & 24.2 & 30.9 & 37.1 & 41.8 & 44.3 & 44.2 & 40.3 & 33.5 & 23.8 & 17.8 \\
\hline Humidity (\%) & 73 & 61 & 51 & 42 & 34 & 28 & 29 & 31 & 35 & 45 & 62 & 72 \\
\hline Wind $(\mathrm{m} / \mathrm{sec})$ & 1.6 & 2 & 2.3 & 2.3 & 2.4 & 3 & 3 & 2.5 & 1.8 & 11.6 & 1.4 & 1.5 \\
\hline Sunshine (h) & 6.2 & 7.2 & 7.9 & 8.5 & 9.2 & 11.2 & 11.4 & 11 & 10.1 & 8.2 & 7.1 & 6.2 \\
\hline Rain (mm) & 16.9 & 14.5 & 17.1 & 12.3 & 3 & 0 & 0 & 0 & 0 & 4.4 & 14 & 15 \\
\hline
\end{tabular}

mean average monthly air temperature, mean sun shine duration, wind speed, mean monthly evaporation, mean relative humidity and rainfall. A summary of these data are listed in Table 3.

\section{MATERIALS AND METHODS}

Estimating the water demand of the crops in Al-Kamaliya irrigation project: The reference Evapotranspiration $\left(\mathrm{ET}_{0}\right)$ was calculated by Penman-Monteith method, using decision support Software-CROPWAT 8.0 developed by FAO. The FAO CROPWAT program includes procedures for reference crop evapotranspiration and crop water requirements and allow the modeling of crop water use under various climate, crop and soil conditions (www.fao.org).

The Penman Monteith method of estimating is expressed in equation:

$$
\mathrm{ET}_{0}=\frac{0.408\left(\mathrm{R}_{\mathrm{n}}-\mathrm{G}\right)+\gamma \frac{900}{\mathrm{~T}+273} \mathrm{U}_{2}\left(\mathrm{e}_{\mathrm{s}}-\mathrm{e}_{\mathrm{a}}\right)}{\Delta+\gamma\left(1+0.34 \mathrm{U}_{2}\right)}
$$

Where:

$\mathrm{ET}_{0}=$ Reference Evapotranspiration $\left(\right.$ mmday $\left.^{-1}\right)$

$\mathrm{R}_{\mathrm{n}}=$ Net Radiation at the crop surface $\left(\mathrm{MJ} \mathrm{m}^{-2}\right.$ day $\left.^{-1}\right)$

$\mathrm{G}=$ Soil heat flux density $\left(\mathrm{MJ} \mathrm{m}^{-2}\right.$ day $^{-1}$

$\mathrm{T}=$ Mean daily air temperature at $2 \mathrm{~m}$ height $\left({ }^{\circ} \mathrm{C}\right)$

$\mathrm{U}_{2}=$ Wind speed at $2 \mathrm{~m}$ height $\left(\mathrm{msec}^{-1}\right)$

$\mathrm{e}_{\mathrm{s}}=$ Saturation vapour pressure $(\mathrm{kPa})$

$\mathrm{e}_{\mathrm{a}}=$ Actual vapour pressure $(\mathrm{kPa})$

$\mathrm{e}_{\mathrm{s}}-\mathrm{e}_{\mathrm{a}}=$ Saturation vapour pressure deficit $(\mathrm{kPa})$

$\triangle \quad=$ Slope vapour pressure curve $\left(\mathrm{kPa}^{\circ} \mathrm{C}^{-1}\right)$

$\checkmark \quad=$ Psychrometric constant $\left(\mathrm{kPa}^{\circ} \mathrm{C}^{-1}\right)$
The empirical formula used for effective rainfall in determining the crop water requirement by CROPWAT while the crop coefficients $\left(\mathrm{K}_{\mathrm{c}}\right)$ used for Al-Hussainiya District in Kerbala:

$$
\mathrm{ET}_{\mathrm{c}}=\mathrm{k}_{\mathrm{c}} * \mathrm{ET}_{\mathrm{o}}
$$

Figure 3 shows using of climatic data from Table 3 in program CROPWAT and the results of crop water requirements illustrated in Table 4 after multiplying ET $_{c}$ by crop area.

Flow measurements at Al-Kamaliya main canal and its distributary canals: The flow applied to the canal Al-Kamaliya comes from the branch canal $\mathrm{BC} 1$ which take its flow from old and new Al-Hussainiya canal (Fig. 1). The water flow in Al-Kamaliya canal were measured in the Winter season from Dec.-May using the devices (ADCP) and the device (current meter). Table 5 and 6 and Fig. 4 show the difference between the required flow obtained by CROPWAT and available flow measured and estimated. As can be seen from Fig. 4, there was an adequate between the flow provided and required during the year. The flow need to be reduced at Nov-Feb and Aug-Oct while increased at months Mar-Jul in order to save a good amount of water. The estimated flow, Table 6, obtained by the program HEC-RAS based on the previous records of water levels at Al-Hussainiya canal and its effect on the water levels and discharges at the branch canal BCl and Al-Kamaliya canal (Fig. 5).

GIS application in irrigation management: A georefrenced image of Al-Kamaliya irrigation project was obtained from the website: bing.com by the use of 


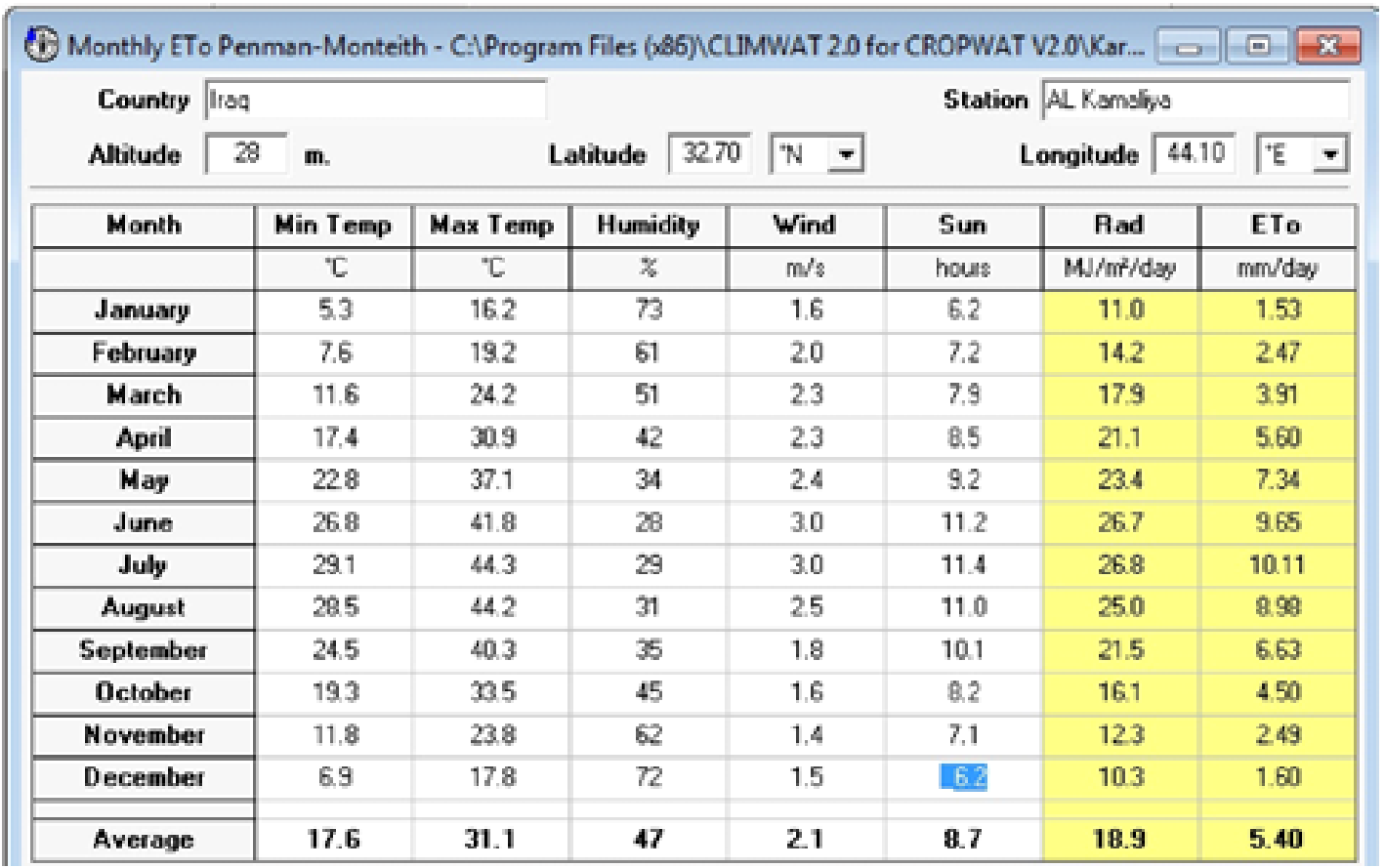

Fig. 3: Inputting climatic data in CROPWAT

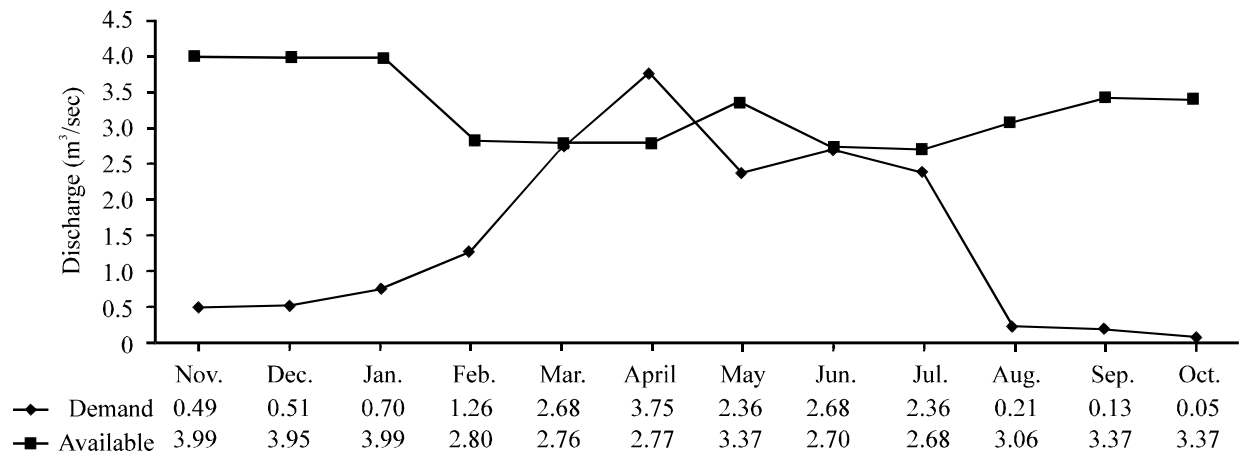

Fig. 4: Over year demand vs. available dischrges

Table 4: Total CWR $\left(\mathrm{m}^{3} / \mathrm{sec}\right)$ for distributary canal area, using crop coefficient $\left(\mathrm{K}_{\mathrm{c}}\right)$ for Al-Hussainiy a District and empirical effective rainfall method

\begin{tabular}{lcccccccccc}
\hline Dis.Month & DC5 & DC7 & Right 1 & Right 2 & DC4 & DC9 & DC8 & DC11 & DC13 & Sum (m $/$ sec) \\
Nov. & 0.0535 & 0.0529 & 0.0392 & 0.0255 & 0.0059 & 0.1068 & 0.0294 & 0.0617 & 0.1401 & 0.5150 \\
Dec. & 0.0535 & 0.0549 & 0.0412 & 0.0265 & 0.0069 & 0.1117 & 0.0314 & 0.0647 & 0.1499 & 0.5407 \\
Jan. & 0.0726 & 0.0745 & 0.0559 & 0.0363 & 0.0088 & 0.1519 & 0.0421 & 0.0882 & 0.2087 & 0.7390 \\
Feb. & 0.1338 & 0.1343 & 0.1000 & 0.0657 & 0.0157 & 0.2734 & 0.0764 & 0.1588 & 0.3763 & 1.3344 \\
Mar. & 0.2878 & 0.2898 & 0.2349 & 0.0846 & 0.0333 & 0.5904 & 0.1098 & 0.3420 & 0.6516 & 2.6242 \\
Apr. & 0.3861 & 0.3906 & 0.3123 & 0.1287 & 0.0441 & 0.7956 & 0.2214 & 0.4608 & 0.9171 & 3.6567 \\
May & 0.2773 & 0.2790 & 0.2457 & 0.0234 & 0.0315 & 0.5670 & 0.1575 & 0.3285 & 0.4176 & 2.3275 \\
Jun. & 0.3299 & 0.3330 & 0.2934 & 0.0297 & 0.0378 & 0.6777 & 0.1881 & 0.3924 & 0.3771 & 2.6591 \\
Jul. & 0.2773 & 0.2790 & 0.2448 & 0.0270 & 0.0315 & 0.5688 & 0.1584 & 0.3294 & 0.4095 & 2.3257 \\
Aug. & 0.0312 & 0.0300 & 0.0220 & 0.0150 & 0.0030 & 0.0610 & 0.0170 & 0.0360 & 0.0140 & 0.2292 \\
Sep. & 0.0195 & 0.0200 & 0.0140 & 0.0090 & 0.0020 & 0.0400 & 0.0110 & 0.0230 & 0.0090 & 0.1475 \\
Oct. & 0.0078 & 0.0070 & 0.0050 & 0.0030 & 0.0010 & 0.0140 & 0.0040 & 0.0080 & 0.0020 & 0.0518 \\
Sum & 1.9450 & 1.6084 & 0.4744 & 0.2215 & 3.9583 & 1.0465 & 2.2935 & 3.6729 & 1.9450 & 17.1508 \\
\hline
\end{tabular}

program SAS planet. ArcCatalogue was used to create the layers for the areas, Al-Kamaliya canal and the drains and adding them to the ArcMap.
ArcMap was used to draw the planted area, Al-Kamaliya canal and the drains and filling the attribute tables of the layers with its properties. 


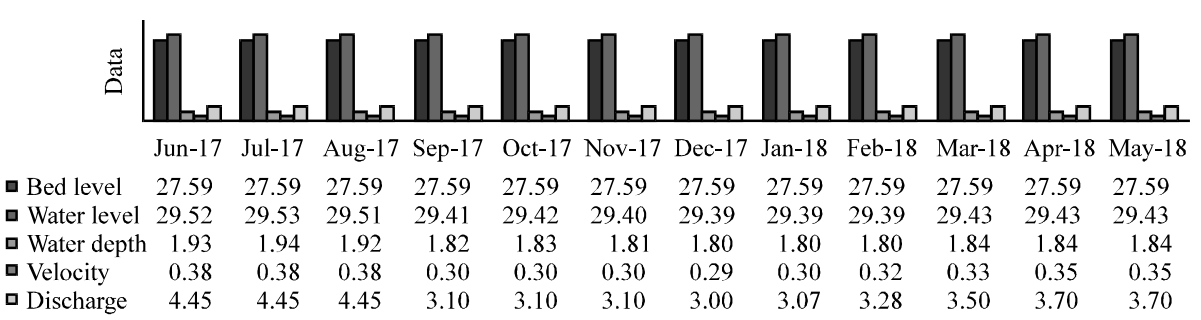

Fig. 5: Over year flow and water level relationship at Al-Kamaliya canal

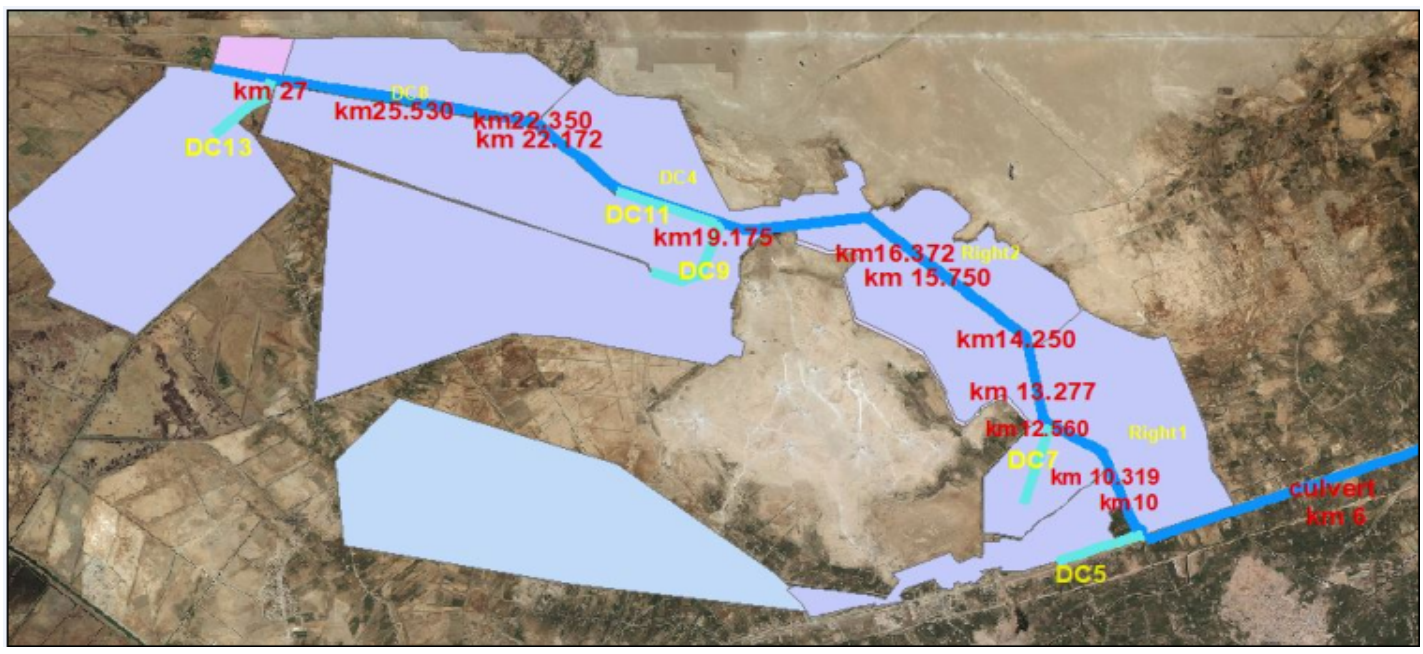

Fig. 6: The locations and distances of distributary canals

Table 5: Al-Kamaliya main canal flow data at upstream (Station 4+000)

\begin{tabular}{lcc}
\hline Canal & Months & Discharge $\left(\mathrm{m}^{3} / \mathrm{sec}\right)$ \\
\hline Kamaliya & Dec. & 3.00 \\
Kamaliya & Jan. & 3.07 \\
Kamaliya & Feb. & 3.28 \\
Kamaliya & Mar. & 3.50 \\
Kamaliya & Apr. & 3.70 \\
Kamaliya & May & 3.70 \\
\hline
\end{tabular}

The areas of the lands around Al-Kamaliya canal were estimated by GIS as shown in Table 7.

Locating the locations and distances of distributary canals branching from Al-Kamaliya main canal (Fig. 6), since, it is not available in the longitudinal section of the canal. Querying the data by interactive selection of layers by ArcMap showing the required water to irrigate the areas around Al-Kamaliya canal (Fig. 7).

Using a simulation program (HEC-RAS): A simulation for the flow to be provided to the distributary canals done by using the software by US Army Crops of Engineering (HEC-RAS) to estimate the value of flow to be increased or decreased in order to obtain the required water level and flow to be provided to these distributary canals (DC9, DC1 1 and DC13). The simulated flow is at the upstream of the distributary canals, so for, estimating the flow at outlets a conveyance efficiency is assumed equal $94 \%$ because the canals are lined with concrete (Table 8).

In order to increase the water flow in far distributary canals DC9, DC11 and DC13. The following scenarios were considered.

Case 1: All outlets and cross regulators are open (normal case).

Case 2: Closing Cross Regulator 2 (CR2) at $0.1 \mathrm{~m}$ (to increase flow at $\mathrm{DC} 9, \mathrm{DC} 11$ ).

Case 3: Closing the outlet DC9, DC11 and DC4 (to increase flow at $\mathrm{DC} 13$ ).

Evaluation of canal performance: The Delivery Performance Ratio (DPR) indicator for the distributary canals is calculated to know if the flow provided is more or lower than required. The DPR is defined as the ratio of actual measured discharge to require or 


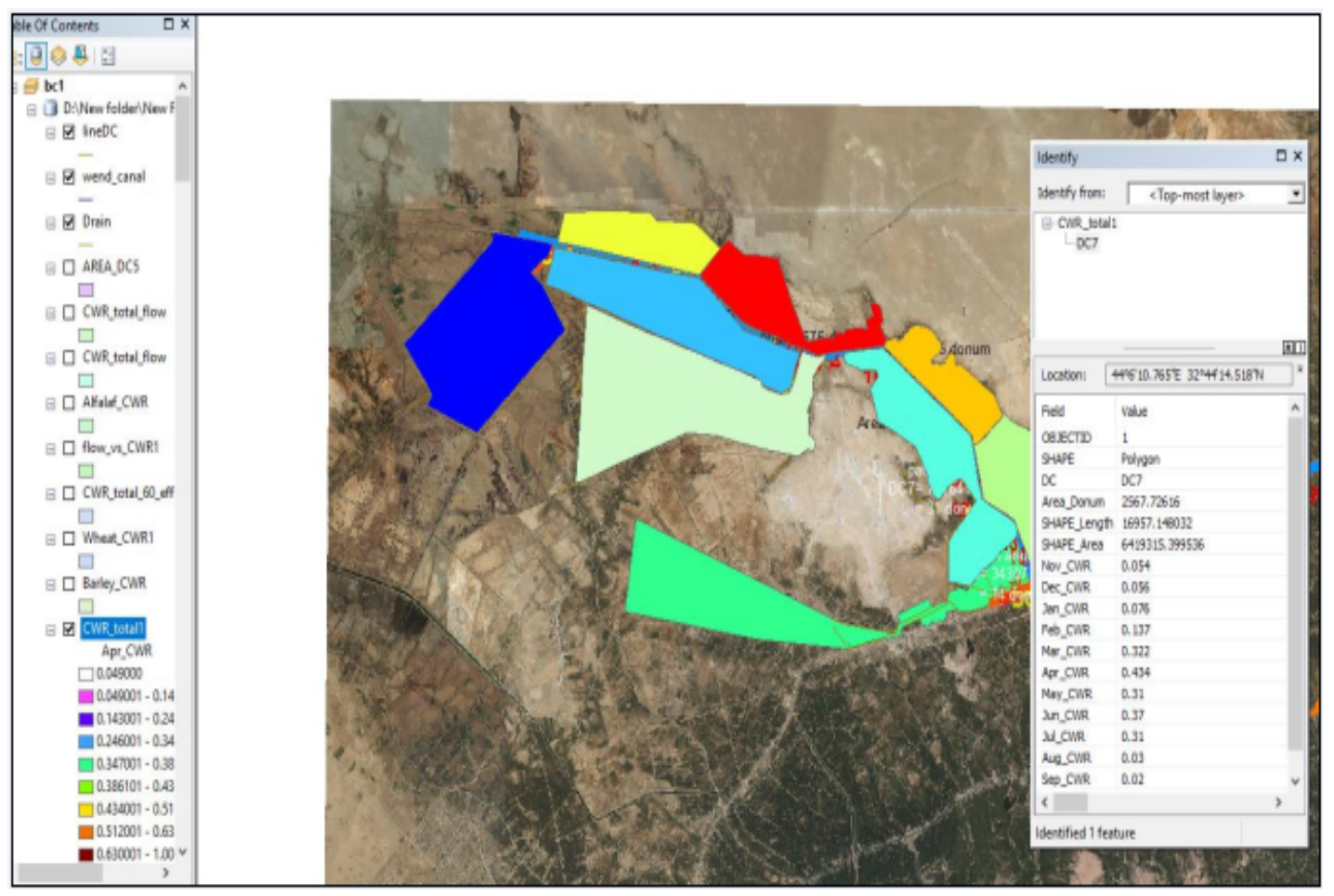

Fig. 7: Querying CWR by GIS

Table 6: Flow data of distributary canals, year (2017-2018)

\begin{tabular}{|c|c|c|c|c|c|c|c|c|c|c|c|c|c|c|}
\hline \multirow{3}{*}{$\begin{array}{l}\text { Outlet } \\
\text { No. }\end{array}$} & \multirow{3}{*}{$\begin{array}{l}\text { Design } \\
\text { discharge } \\
\left(\mathrm{m}^{3} / \mathrm{sec}\right)\end{array}$} & \multirow[b]{3}{*}{ Station } & \multicolumn{12}{|c|}{ Over year discharges $\left(\mathrm{m}^{3} / \mathrm{sec}\right)$} \\
\hline & & & \multicolumn{6}{|c|}{ Estimated (2017) } & \multicolumn{6}{|c|}{ Measured (2018) } \\
\hline & & & Jun. & Jul. & Aug. & Sep. & Oct. & Nov. & Dec. & Jan. & Feb. & Mar. & April & May \\
\hline DC5 & 3.0 & $16+900$ & 1.20 & 1.20 & 1.20 & 0.70 & 0.70 & 0.71 & 0.71 & 0.70 & 0.71 & 0.75 & 0.90 & 0.90 \\
\hline Right1 & 0.5 & $16+300$ & 0.23 & 0.22 & 0.24 & 0.19 & 0.20 & 0.20 & 0.20 & 0.20 & 0.20 & 0.21 & 0.22 & 0.22 \\
\hline DC7 & 3.0 & $14+600$ & 0.55 & 0.55 & 0.55 & 0.45 & 0.45 & 0.45 & 0.40 & 0.40 & 0.40 & 0.45 & 0.50 & 0.50 \\
\hline Right2 & 0.5 & $12+500$ & 0.26 & 0.23 & 0.20 & 0.20 & 0.20 & 0.20 & 0.20 & 0.20 & 0.21 & 0.20 & 0.23 & 0.23 \\
\hline DC9 & 1.3 & $7+500$ & 0.45 & 0.45 & 0.45 & 0.32 & 0.30 & 0.30 & 0.29 & 0.30 & 0.28 & 0.35 & 0.35 & 0.35 \\
\hline DC4 & 0.6 & $7+400$ & 0.35 & 0.35 & 0.35 & 0.27 & 0.26 & 0.26 & 0.25 & 0.25 & 0.25 & 0.30 & 0.32 & 0.32 \\
\hline DC11 & 1.3 & $7+400$ & 0.35 & 0.35 & 0.40 & 0.27 & 0.25 & 0.26 & 0.25 & 0.25 & 0.25 & 0.30 & 0.30 & 0.30 \\
\hline DC8 & 0.6 & $4+500$ & 0.30 & 0.30 & 0.30 & 0.20 & 0.20 & 0.20 & 0.18 & 0.20 & 0.20 & 0.30 & 0.25 & 0.25 \\
\hline $\mathrm{DC} 13$ & 1.3 & $0+00$ & 0.30 & 0.30 & 0.30 & 0.20 & 0.20 & 0.20 & 0.20 & 0.20 & 0.18 & 0.20 & 0.30 & 0.30 \\
\hline Sum & - & - & 2.7 & 2.68 & 3.06 & 3.37 & 3.37 & 3.99 & 3.95 & 3.99 & 2.80 & 2.76 & 2.77 & 3.37 \\
\hline
\end{tabular}

Table 7: Area of the lands around Al-kamaliya canal by GIS

\begin{tabular}{lc}
\hline Land & Area (donum) \\
\hline DC5 & 5479 \\
DC7 & 2559 \\
Right 1 & 2264 \\
Right 2 & 1225 \\
DC4 & 1576 \\
DC9 & 5145 \\
DC8 & 1687 \\
DC11 & 2980 \\
DC13 & 4062 \\
Sum & 26975 \\
\hline
\end{tabular}

intended discharge in a certain point through the system which has been used by Clemmens and Replogle (1989),
Molden and Gates (1990), Bos et al. (1993), MurrayRust and Snellen (1993). The equation for DPR is:

$$
\mathrm{DPR}=\frac{\text { Actual delivered flow of water }}{\text { Re quired or intended flow of water }}
$$

The delivery performance classifies as excessive if DPR is $>1.15$, moderate flow if DPR within the 0.9-1.15 and inadequate flow if DPR $<0.9$. The actual flow obtained from measured and simulated scenarios (Table 8-11) while the required flow obtained from CROPWAT (Table 3). 
Table 8: Over year discharges $\left(\mathrm{m}^{3} / \mathrm{sec}\right)$ with conveyance efficiency $94 \%$

\begin{tabular}{|c|c|c|c|c|c|c|c|c|c|c|c|c|}
\hline \multirow{2}{*}{$\begin{array}{l}\text { Outlet } \\
\text { No. }\end{array}$} & \multirow{2}{*}{$\begin{array}{l}\text { Design } \\
\text { discharge } \\
\left(\mathrm{m}^{3} / \mathrm{sec}\right)\end{array}$} & \multirow[b]{2}{*}{ Station } & \multicolumn{10}{|c|}{ Over y ear discharge $\left(\mathrm{m}^{3} / \mathrm{sec}\right)$ conveyance efficiency $(0.94)$} \\
\hline & & & Jan. & Feb. & Mar. & April & May & Jun. & Jul. & Aug. & Sep. & Oct. \\
\hline DC5 & 3.0 & $16+900$ & 0.6580 & 0.6674 & 0.7050 & 0.8460 & 0.8460 & 1.1280 & 1.1280 & 1.1280 & 0.6580 & 0.658 \\
\hline Right & 0.5 & $16+300$ & 0.1880 & 0.1880 & 0.1974 & 0.2068 & 0.2068 & 0.2162 & 0.2068 & 0.2256 & 0.1786 & 0.188 \\
\hline DC7 & 3.0 & $14+600$ & 0.3760 & 1.3760 & 0.4230 & 0.4700 & 0.4700 & 0.5170 & 0.5170 & 0.5170 & 0.4230 & 0.423 \\
\hline Right 2 & 0.5 & $12+500$ & 0.1880 & 0.1974 & 0.1880 & 0.2162 & 0.2162 & 0.2444 & 0.2162 & 0.1880 & 0.1880 & 0.188 \\
\hline DC 9 & 3.0 & $7+500$ & 0.2820 & 0.2632 & 0.3290 & 0.3290 & 0.3290 & 0.4230 & 0.4230 & 0.4230 & 0.3290 & 0.329 \\
\hline DC4 & 0.7 & $7+400$ & 0.2350 & 0.2350 & 0.2820 & 0.3008 & 0.3008 & 0.3290 & 0.3290 & 0.3290 & 0.2820 & 0.282 \\
\hline DC11 & 3.0 & $7+400$ & 0.2350 & 0.2350 & 0.2820 & 0.2820 & 0.2820 & 0.3290 & 0.3290 & 0.3760 & 0.3760 & 0.282 \\
\hline DC8 & 0.7 & $4+500$ & 0.1880 & 0.1880 & 0.2820 & 0.2350 & 0.2350 & 0.2820 & 0.2820 & 0.2820 & 0.1880 & 0.188 \\
\hline$\underline{\mathrm{DC} 13}$ & 3.0 & $0+500$ & 0.1880 & 0.1692 & 0.1880 & 0.2820 & 0.2820 & 0.2820 & 0.2820 & 0.2820 & 0.1880 & 0.188 \\
\hline
\end{tabular}

Table 9: Delivery performance ratio for simulated scenario case 1

\begin{tabular}{|c|c|c|c|c|c|c|c|c|c|c|c|c|c|c|}
\hline \multirow{3}{*}{$\begin{array}{l}\text { Outlet } \\
\text { No. }\end{array}$} & \multirow{3}{*}{$\begin{array}{c}\text { Design } \\
\text { discharge } \\
\left(\mathrm{m}^{3} / \mathrm{sec}\right) \\
\end{array}$} & \multirow[b]{3}{*}{ Station } & \multicolumn{12}{|c|}{ Case 1 DPR } \\
\hline & & & \multicolumn{7}{|l|}{2017} & \multicolumn{5}{|c|}{2018} \\
\hline & & & Jun. & Jul. & Aug. & Sep. & Oct. & Nov. & Dec. & Jan. & Feb. & Mar. & April & May \\
\hline DC5 & 3 & $16+900$ & 3.4 & 4.1 & 36.2 & 33.8 & 84.6 & 12.5 & 12.5 & 9.1 & 5.0 & 2.5 & 2.2 & 3.1 \\
\hline Right 1 & 0.5 & $16+300$ & 0.7 & 0.9 & 10.5 & 12.9 & 38.0 & 4.8 & 4.6 & 3.4 & 1.9 & 0.9 & 0.7 & 0.9 \\
\hline DC7 & 3 & $14+600$ & 1.6 & 1.9 & 17.3 & 21.0 & 60.0 & 7.9 & 6.9 & 5.1 & 2.8 & 1.4 & 1.2 & 1.7 \\
\hline Right 2 & 0.5 & $12+500$ & 8.1 & 8.1 & 12.7 & 21.1 & 63.3 & 7.5 & 7.2 & 5.2 & 3.0 & 2.2 & 1.7 & 9.4 \\
\hline DC9 & 1.3 & $7+500$ & 0.6 & 0.7 & 6.9 & 5.5 & 16.4 & 2.2 & 2.1 & 1.6 & 1.0 & 0.6 & 0.4 & 0.6 \\
\hline DC4 & 0.6 & $7+400$ & 8.7 & 0.0 & 110.0 & 125.0 & 240.0 & 40.7 & 34.8 & 27.3 & 15.3 & 8.4 & 6.8 & 9.5 \\
\hline DC11 & 1.3 & $7+400$ & 0.8 & 1.0 & 10.6 & 9.1 & 27.5 & 3.4 & 3.4 & 2.4 & 1.5 & 0.8 & 0.6 & 0.9 \\
\hline DC8 & 0.6 & $4+500$ & 1.5 & 1.8 & 16.5 & 17.3 & 47.5 & 6.5 & 5.4 & 4.5 & 2.5 & 2.6 & 1.1 & 1.5 \\
\hline DC13 & 1.3 & $0+000$ & 0.7 & 0.7 & 20.0 & 21.1 & 95.0 & 1.4 & 1.3 & 0.9 & 0.5 & 0.3 & 0.3 & 0.7 \\
\hline
\end{tabular}

Table 10: Delivery performance ratio for simulated scenario case 2

\begin{tabular}{|c|c|c|c|c|c|c|c|c|c|c|c|c|c|c|}
\hline \multirow{3}{*}{$\begin{array}{l}\text { Outlet } \\
\text { No. }\end{array}$} & \multirow{3}{*}{$\begin{array}{c}\text { Design } \\
\text { discharge } \\
\left(\mathrm{m}^{3} / \mathrm{sec}\right)\end{array}$} & \multirow[b]{3}{*}{ Station } & \multicolumn{12}{|c|}{ Case 2 DPR } \\
\hline & & & \multicolumn{7}{|l|}{2017} & \multicolumn{5}{|l|}{2018} \\
\hline & & & Jun. & Jul. & Aug. & Sep. & Oct. & Nov. & Dec. & Jan. & Feb. & Mar. & April & May \\
\hline DC5 & 3 & $16+900$ & 3.637 & 4.327 & 38.462 & 35.897 & 89.744 & 13.084 & 13.084 & 9.642 & 5.306 & 2.606 & 2.331 & 3.246 \\
\hline Right 1 & 0.5 & $16+300$ & 1.022 & 1.225 & 13.636 & 14.286 & 40.000 & 5.102 & 4.854 & 3.578 & 2.000 & 0.894 & 0.704 & 0.895 \\
\hline DC7 & 3 & $14+600$ & 1.652 & 1.971 & 18.333 & 20.000 & 57.143 & 7.561 & 7.286 & 5.369 & 2.978 & 1.553 & 1.280 & 1.792 \\
\hline Right 2 & 0.5 & $12+500$ & 10.101 & 11.111 & 20.000 & 22.222 & 66.667 & 7.843 & 7.547 & 5.510 & 3.196 & 2.600 & 1.787 & 9.829 \\
\hline DC9 & 1.3 & $7+500$ & 1.328 & 1.582 & 14.754 & 12.500 & 35.714 & 4.682 & 4.476 & 1.975 & 2.377 & 1.186 & 0.880 & 1.235 \\
\hline DC4 & 0.6 & $7+400$ & 10.582 & 10.740 & 133.333 & 150.000 & 300.000 & 50.847 & 43.478 & 56.818 & 19.108 & 12.012 & 9.070 & 12.698 \\
\hline DC11 & 1.3 & $7+400$ & 1.310 & 1.821 & 16.667 & 17.391 & 50.000 & 6.483 & 6.182 & 4.535 & 2.519 & 1.754 & 0.868 & 1.218 \\
\hline DC8 & 0.6 & $4+500$ & 0.000 & 0.000 & 0.000 & 0.000 & 0.000 & 0.000 & 0.000 & 0.000 & 0.000 & 0.000 & 0.000 & 0.000 \\
\hline DC13 & 1.3 & $0+000$ & 0.000 & 0.000 & 0.000 & 0.000 & 0.000 & 0.000 & 0.000 & 0.000 & 0.000 & 0.000 & 0.000 & 0.000 \\
\hline
\end{tabular}

Table 11: Delivery performance ratio for simulated scenario case 3

\begin{tabular}{|c|c|c|c|c|c|c|c|c|c|c|c|c|c|c|}
\hline \multirow{3}{*}{$\begin{array}{l}\text { Outlet } \\
\text { No. }\end{array}$} & \multirow{3}{*}{$\begin{array}{c}\text { Design } \\
\text { discharge } \\
\left(\mathrm{m}^{3} / \mathrm{sec}\right)\end{array}$} & \multirow[b]{3}{*}{ Station } & \multicolumn{12}{|c|}{ Case 3 DPR } \\
\hline & & & \multicolumn{7}{|c|}{2017} & \multicolumn{5}{|c|}{2018} \\
\hline & & & Jun. & Jul. & Aug. & Sep. & Oct. & Nov. & Dec. & Jan. & Feb. & Mar. & April & May \\
\hline DC5 & 3 & $16+900$ & 3.6 & 4.3 & 38.5 & 35.9 & 89.7 & 13.1 & 13.1 & 9.6 & 5.2 & 2.5 & 1.9 & 3.2 \\
\hline Right 1 & 0.5 & $16+300$ & 1.0 & 1.2 & 13.6 & 14.3 & 40.0 & 5.1 & 4.9 & 3.6 & 2.0 & 0.9 & 0.6 & 0.9 \\
\hline DC7 & 3 & $14+600$ & 1.7 & 2.0 & 18.3 & 20.0 & 57.1 & 7.6 & 7.3 & 5.4 & 3.0 & 1.4 & 1.0 & 1.4 \\
\hline Right 2 & 0.5 & $12+500$ & 10.1 & 11.1 & 20.0 & 22.2 & 66.7 & 7.8 & 7.5 & 5.5 & 3.0 & 2.4 & 1.7 & 9.8 \\
\hline DC9 & 1.3 & $7+500$ & 0.0 & 0.0 & 0.0 & 0.0 & 0.0 & 0.0 & 0.0 & 0.0 & 0.0 & 0.0 & 0.0 & 0.0 \\
\hline DC4 & 0.6 & $7+400$ & 0.0 & 0.0 & 0.0 & 0.0 & 0.0 & 0.0 & 0.0 & 0.0 & 0.0 & 0.0 & 0.0 & 0.0 \\
\hline DC11 & 1.3 & $7+400$ & 0.0 & 0.0 & 0.0 & 0.0 & 0.0 & 0.0 & 0.0 & 0.0 & 0.0 & 0.0 & 0.0 & 0.0 \\
\hline DC8 & 0.6 & $4+500$ & 3.2 & 3.8 & 35.3 & 45.5 & 100.0 & 13.6 & 12.7 & 9.5 & 5.2 & 3.6 & 2.3 & 3.2 \\
\hline DC13 & 1.3 & $0+000$ & 1.9 & 1.7 & 50.0 & 66.7 & 250.0 & 3.6 & 3.3 & 2.4 & 1.3 & 0.8 & 0.5 & 1.3 \\
\hline
\end{tabular}

\section{RESULTS AND DISCUSSION}

From Fig. 3, the flow provided at beginning of Winter and end of Summer seasons is greater than required and need to be reduced. The required flow to irrigate the crops in Al-Kamaliya District varies around the months of the year. It is found that at months from (January-February) the provided flow is more than required, especially, at area of DC4, DC8, DC5 and Right 2. The flow provided at warmer months from (March-July) is lower than required at area of DC9, DC1 1, DC13 (Table 9). From the DPR for the simulated scenario (Case 1) of the flow in the distributary canals it is shown that the flow need to be increased in the distributary canals (DC11, DC9 and 
DC13) for the months (March-July). The scenario (Case 2) Table 10 could provide adequate water to distributary canals (DC9, DC11) and excessive water to DC4 in months (March-July) (Case 3) scenario show that the flow increased to be adequate in month May and unadequate at months (March-April) and excessive in all other months (Table 11).

\section{CONCLUSION}

More water could be saved by providing right amount of water at specified season. From the resulted DPR of flow values from scenarios suggested, it is shown that the flow values increased highly in DC4 and moderately in DC9 or DC11 when (closing CR2), so, it is recommended to close DC4 partially or open CR2 at $0.2 \mathrm{~m}$ in order to increase the water flow at DC11. At scenario (closing DC9, DC11 and DC4), the value at DC8 increase more than required while at DC13 remained low, so, it is recommended to close the DC8 partially to increase the flow reach to $\mathrm{DC} 13$.

\section{AKNOWLEDGEMENTS}

Praise and glory be to almighty Allah with whose gracious help, it was possible to accomplish this research. The researcher would like to thank supervisor Ass. Prof. Dr. Husam Hadi Alwan for his valuable support and guidance throughout the research. Sincere thanks also to co-supervisor Prof. Zuhair Abd Alwahab Aljwahery for his valuable assistance, suggestions, advice, guidance and encouragement throughout the research. I would like to thank the head Department of Civil Engineering in College of Engineering in University of Kerbala for giving us such an excellent opportunity to commence this project in the first instance, the employees of the department of water resources in Kerbala Province. The thanks also to all master students who assist me and my parents for their help in facilitate and complete the practical aspect for this research.

\section{REFERENCES}

Bos, M.G., D.H. Murray-Rust, D.J. Merrey, H.G. Johnson and W.B. Snellen, 1993. Methodologies for assessing performance of irrigation and drainage management. Irrig. Drain. Syst., 7: 231-261.

Clemmens, A.J. and J.A. Replogle, 1989. Control of irrigation canal networks. J. Irrig. Drain. Eng., 115: 96-110.

Ghumman, A.R., M.A.K. Tarrar and A.A. Tahir, 2004. Investigation of optimal use of canal water in Pakistan. Proc. Intl. Conf. Water Resour. Arid Environ., 1: 1-8.

Maatooq, J.S. and G.A. Kadhim, 2016. Evaluation of the hydraulic performance indicators for Al-Ibrahim Irrigation Canal in the South of Iraq. Eng. Technol. J., 34: 623-635.

Molden, D.J. and T.K. Gates, 1990. Performance measures for evaluation of irrigation-water-delivery systems. J. Irrig. Drain. Eng., 116: 804-823.

Murray-Rust, D.H. and W.B. Snellen, 1993. Irrigation System Performance Assessment and Diagnosis. International Water Management Institute (IWMI), Colombo, Sri Lanka, ISBN:92-9090-192-6, Pages: 148.

Serede, I.J., B.M. Mutua and J.M. Raude, 2015. A review for hydraulic analysis of irrigation canals using HEC-RAS Model: A case study of Mwea irrigation scheme, Kenya. Hydrol., 2: 1-5.

Shahrokhnia, M.A. and M. Javan, 2005. Performance assessment of Doroodzan irrigation network by steady state hydraulic modeling. Irrig. Drain. Syst., 19: 189-206. 